\title{
Importance of knowing the level of sacral hiatus for caudal epidural anesthesia
}

\author{
NADEEM, G.* \\ Assistant Professor, College of Dentistry, Ajman University of Science and Technology, \\ Ajman, United Arab Emirates \\ *E-mail: g.nadeem@ajman.ac.ae
}

\begin{abstract}
Introduction and Materials and Methods: The Study was carried out on 100 dry human sacra to know the Anatomical variations of sacral hiatus. Results: Different shapes of sacral hiatus were observed which included- Inverted U (56\%), Inverted V (14\%), Irregular (16\%), Dumb-bell (10\%), Bifid (2\%) and Elongated $(2 \%)$. The apex of the sacral hiatus was most commonly found at the level of 3 rd sacral vertebrae in $62 \%$. The mean length of sacral hiatus was $25.2 \mathrm{~mm}$, the mean anteroposterior diameter of sacral canal at the apex of sacral hiatus was $5.53 \mathrm{~mm}$. The mean distance between sacral cornu at the base of sacral hiatus was observed to be $19.5 \mathrm{~mm}$. Conclusion: This study was done to clarify the anatomical variations of sacral hiatus using bony landmarks of sacrum for improving the reliability of caudal epidural anesthesia and to improve its success rate and reduce the complications and failure rate.
\end{abstract}

Keywords: sacral hiatus, caudal epidural anesthesia, sacrum.

\section{Introduction}

The opening that is present at the caudal end of sacral canal is known as sacral hiatus. Failure of fusion of the laminae of the $4^{\text {th }}$ or $5^{\text {th }}$ sacral vertebrae results in its formation (more usually the $5^{\text {th }}$ sacral vertebrae). It is located inferior to $3^{\text {rd }}$ or $4^{\text {th }}$ fused sacral spines or lower end of median sacral crest. This hiatus is surface marked about 2 inches above the tip of coccyx under the skin covering the natal cleft (WILLIAMS, 2000).

The lower sacral nerve roots, coccygeal nerve roots, filum terminale and fibro-fatty tissue forms the content of this sacral hiatus. This hiatus is covered by superficial posterior coccygeal ligament which is attached to the margins of the hiatus and the deep posterior sacro-coccygeal ligament attached to the floor of sacral hiatus.

This sacral hiatus has been utilized for administration of Epidural anesthesia in orthopedics for diagnosis and treatment of various diseases (SEKIGUCHI, YABUKI, SATON et al., 2004) and also commonly used in Obstetrics (EDWARDS and HINGSON, 1942).

The success, dependability and reliability of caudal epidural anesthesia depends upon structural and anatomical variations of sacral hiatus (SEKIGUCHI, YABUKI, SATON et al., 2004; KUMAR, PANDEY, BAJPAI et al. 1992; TROTTER and LANIER, 1945; SENOGLU, SENOGLU, OKSUZ et al., 2005; CHEN, TANG, HSU et al., 2004; WHITE, DERBY and WYNNE, 1980; LETTERMAN and TROTTER, 1944).

The Present study was made to analyze the Anatomical Variations of sacral hiatus in the Caucasian population living in Germany. Hence the study is about the Caucasian race in contrast to other studies which were done on other races.

\section{Materials and Methods}

The study was conducted in the Department of Anatomy, College of Medicine, King Khalid University, Kingdom of Saudi Arabia (K.S.A). These sacra were procured from Germany and imported to K.S.A. 100 dry human sacra were collected and each sacrum was studied for different features of sacral hiatus with regards to:

- Shape of hiatus.

- Level of apex of hiatus.

- Level of base of hiatus.

- Length of hiatus- measured from apex to midpoint of base.

- Antero-posterior diameter of sacral hiatus at the apex.

- Transverse width of sacral hiatus at the base- measured between the inner aspect of inferior limit of sacral cornu.

The measurements were taken with the help of vernier caliper (Least count- $0.1 \mathrm{~mm}$ ), divider and steel measuring tape.

Observations and Results are presented in Tables 1-7 and in Figures 1-6.

\section{Discussion}

Study on the variations related to anatomical features of sacral hiatus and the dorsal wall of sacral canal is associated with its Clinical applications in the caudal epidural anesthesia.

The lower end of sacral canal is an arch shaped sacral hiatus (WILLIAMS, 2000). Sacral hiatus has a somewhat triangular outline when seen from dorsal aspect (TROTTER and LETTERMAN, 1944). Kumar, Pandey, Bajpai et al. (1992) and Nagar (2004) noted various shapes of sacral 
Table 1. Shape of sacral hiatus $(n=100)$.

\begin{tabular}{|c|c|c|c|}
\hline S.No & Shape & Number & Percentage \\
\hline 1. & Inverted U & 56 & $56 \%$ \\
\hline 2. & Inverted V & 14 & $14 \%$ \\
\hline 3. & Irregular & 16 & $16 \%$ \\
\hline 4. & Dumb-bell & 10 & $10 \%$ \\
\hline 5. & Bifid & 2 & $2 \%$ \\
\hline 6. & Elongated & 2 & $2 \%$ \\
\hline
\end{tabular}

Table 2. Location of Apex in Relation to Level of Sacral Vertebrae ( $n=100)$.

\begin{tabular}{cccc}
\hline S.No & Location of Apex & Number & Percentage \\
\hline 1. & $3^{\text {rd }}$ Sacral vertebrae & 62 & $62 \%$ \\
2. & $4^{\text {th }}$ Sacral vertebrae & 34 & $34 \%$ \\
3. & $2^{\text {nd }}$ Sacral vertebrae & 2 & $2 \%$ \\
4. & $5^{\text {th }}$ Sacral vertebrae & 2 & $2 \%$ \\
\hline
\end{tabular}

Table 3. Location of Base of Hiatus in Relation to Sacral /Coccygeal Vertebrae ( $n=100)$.

\begin{tabular}{cccc}
\hline S.No & Location of Base & Number & Percentage \\
\hline 1. & $5^{\text {th }}$ Sacral vertebrae & 62 & $62 \%$ \\
2. & $4^{\text {th }}$ Sacral vertebrae & 24 & $24 \%$ \\
3. & Coccyx & 14 & $14 \%$ \\
\hline
\end{tabular}

Table 4. Length of sacral hiatus from Apex to midpoint of Base $(n=100)$.

\begin{tabular}{cccc}
\hline S.No & Length & Number & Percentage \\
\hline 1. & $0-10 \mathrm{~mm}$ & 04 & $04 \%$ \\
2. & $11-20 \mathrm{~mm}$ & 15 & $15 \%$ \\
3. & $21-30 \mathrm{~mm}$ & 42 & $42 \%$ \\
4. & $31-40 \mathrm{~mm}$ & 28 & $28 \%$ \\
5. & $41-50 \mathrm{~mm}$ & 07 & $07 \%$ \\
6. & $>51 \mathrm{~mm}$ & 04 & $04 \%$ \\
\hline
\end{tabular}

Table 5. Antero-Posterior diameter of Sacral canal at the Level of Apex $(n=100)$.

\begin{tabular}{cccc}
\hline S.No & Diameter & Number & Percentage \\
\hline 1. & $0-3 \mathrm{~mm}$ & 05 & $05 \%$ \\
2. & $4-6 \mathrm{~mm}$ & 60 & $60 \%$ \\
3. & $7-9 \mathrm{~mm}$ & 30 & $30 \%$ \\
4. & $>9 \mathrm{~mm}$ & 05 & $05 \%$ \\
\hline
\end{tabular}

Table 6. Distance between Sacral Cornu at the Base of sacral hiatus $(n=100)$.

\begin{tabular}{cccc}
\hline S.No & Distance & Number & Percentage \\
\hline 1. & $0-5 \mathrm{~mm}$ & 02 & $02 \%$ \\
2. & $6-10 \mathrm{~mm}$ & 12 & $12 \%$ \\
3. & $10-15 \mathrm{~mm}$ & 34 & $34 \%$ \\
4. & $>15 \mathrm{~mm}$ & 52 & $52 \%$ \\
\hline
\end{tabular}


Table 7. Features and dimensions of the sacral hiatus.

\begin{tabular}{|c|c|c|c|c|c|c|}
\hline Features of Sacral Hiatus & $\begin{array}{l}\text { Present } \\
\text { Study }\end{array}$ & $\begin{array}{l}\text { Nagar } \\
(2004)\end{array}$ & $\begin{array}{c}\text { Kumar, } \\
\text { Pandey, } \\
\text { Bajpai et al. } \\
(1992)\end{array}$ & $\begin{array}{l}\text { Sekiguchi, } \\
\text { Yabuki, } \\
\text { Saton et al. } \\
(2004)\end{array}$ & $\begin{array}{c}\text { Trotter } \\
\text { and Lanier } \\
(1945)\end{array}$ & $\begin{array}{c}\text { Lanier, } \\
\text { McKnight } \\
\text { and Trotter } \\
(1944)\end{array}$ \\
\hline \multicolumn{7}{|l|}{ - Shape } \\
\hline - Inverted U and Inverted V. & $70 \%$ & $68.5 \%$ & $76.3 \%$ & - & - & - \\
\hline - Dumb-bell & $10 \%$ & $13.3 \%$ & $7.63 \%$ & - & - & - \\
\hline - Bifid & $2 \%$ & $1.5 \%$ & - & $3 \%$ & & \\
\hline - Elongated & $2 \%$ & - & - & & & \\
\hline - Irregular & $16 \%$ & $14.1 \%$ & - & & & \\
\hline - Complete agenesis & - & $1.5 \%$ & $1.49 \%$ & & & \\
\hline - Absent hiatus & - & $0.7 \%$ & $0.99 \%$ & & & \\
\hline \multicolumn{7}{|l|}{ - Location of Apex- } \\
\hline - $3^{\text {rd }}$ sacral vertebrae & $62 \%$ & $37.3 \%$ & - & - & - & - \\
\hline - $5^{\text {th }}$ sacral vertebrae & $2 \%$ & $3.4 \%$ & - & - & - & - \\
\hline - $2^{\text {nd }}$ sacral vertebrae & $2 \%$ & $3.4 \%$ & - & - & - & - \\
\hline \multicolumn{7}{|l|}{ - Location of base of hiatus- } \\
\hline - $4^{\text {th }}$ sacral vertebrae & $24 \%$ & $11.1 \%$ & - & - & - & - \\
\hline - c. Coccyx & $14 \%$ & $16.3 \%$ & - & - & - & - \\
\hline - Mean length of sacral hiatus & $25.2 \mathrm{~mm}$ & $20.5 \mathrm{~mm}$ & $20 \mathrm{~mm}$ & - & $24.8 \mathrm{~mm}$ & $25.3 \mathrm{~mm}$ \\
\hline $\begin{array}{l}\text { - Mean diameter of sacral } \\
\text { canal }\end{array}$ & $5.53 \mathrm{~mm}$ & $4.8 \mathrm{~mm}$ & $4.8 \mathrm{~mm}$ & $6.0 \mathrm{~mm}$ & $5.3 \mathrm{~mm}$ & $6.1 \mathrm{~mm}$ \\
\hline $\begin{array}{l}\text { - Mean width at base of sacral } \\
\text { hiatus }\end{array}$ & $19.5 \mathrm{~mm}$ & $10 \mathrm{~mm}$ & $12.5 \mathrm{~mm}$ & $10.2 \mathrm{~mm}$ & $17 \mathrm{~mm}$ & $19.3 \mathrm{~mm}$ \\
\hline
\end{tabular}

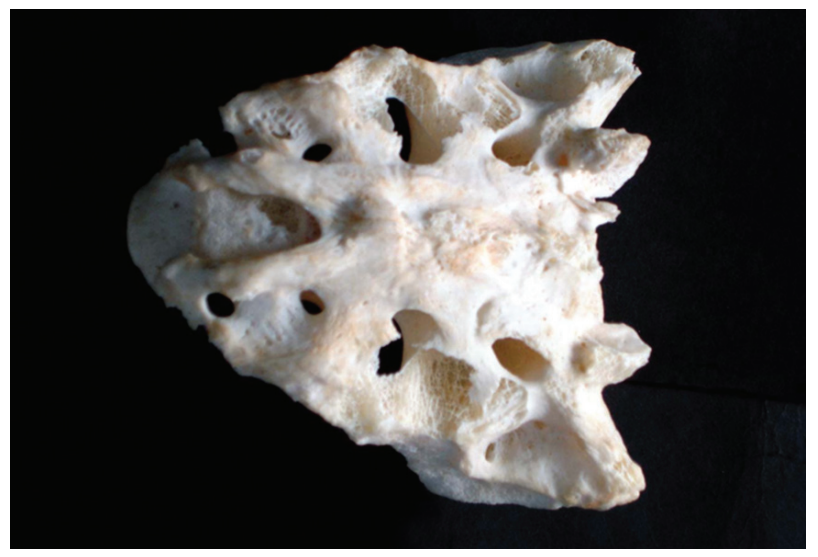

Figure 1. Inverted U shaped sacral hiatus.

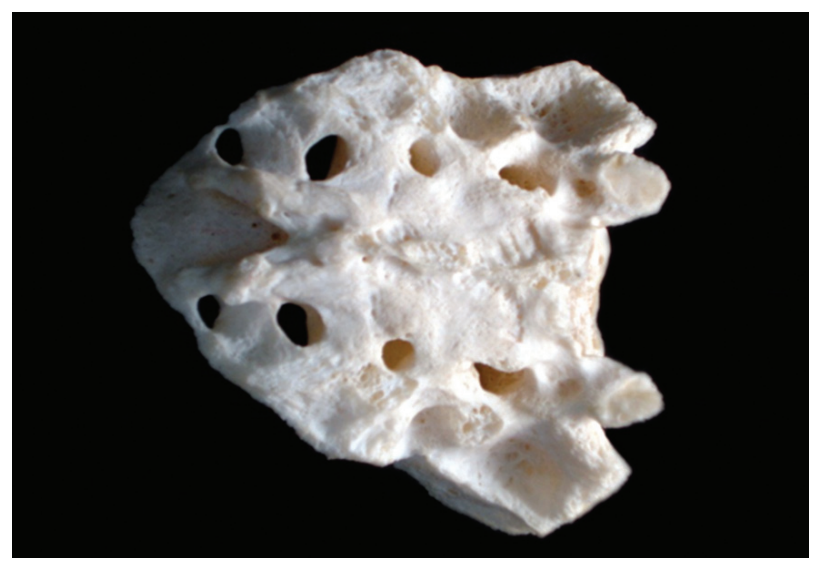

Figure 2. Inverted V shaped sacral hiatus.

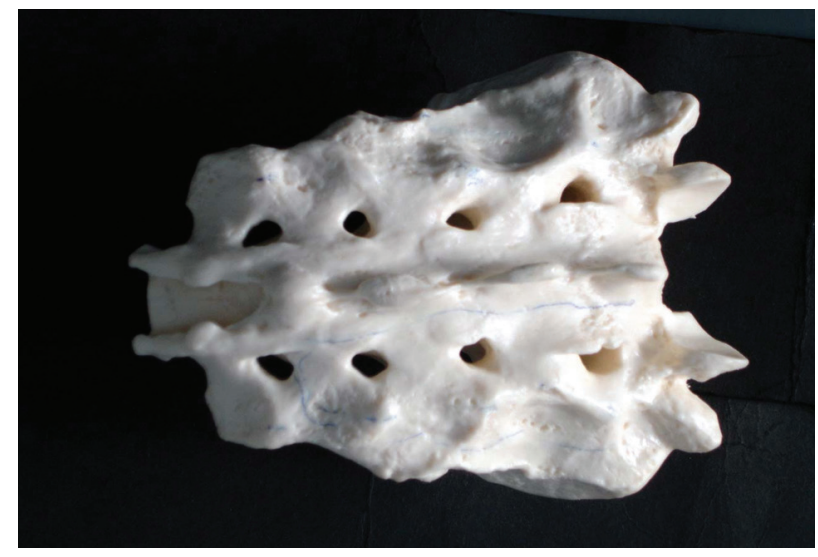

Figure 3. Dumbbell shaped sacral hiatus.

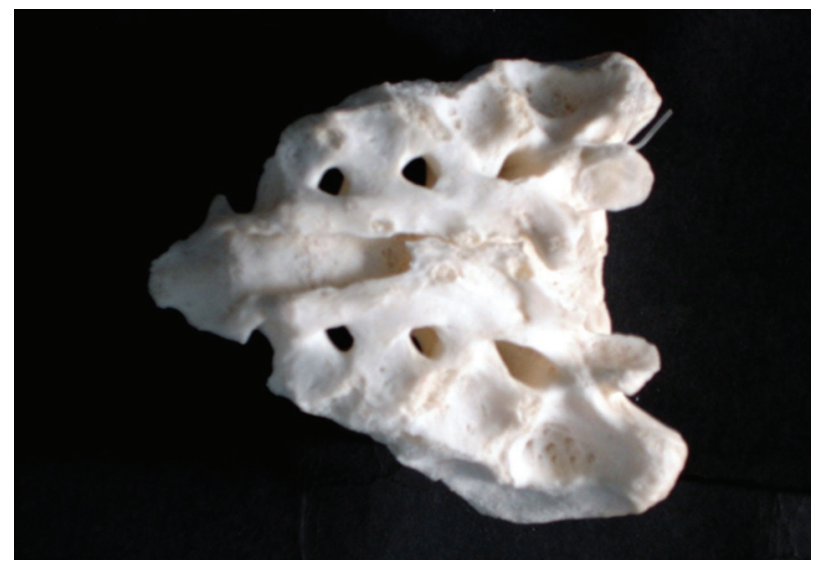

Figure 4. Elongated sacral hiatus. 


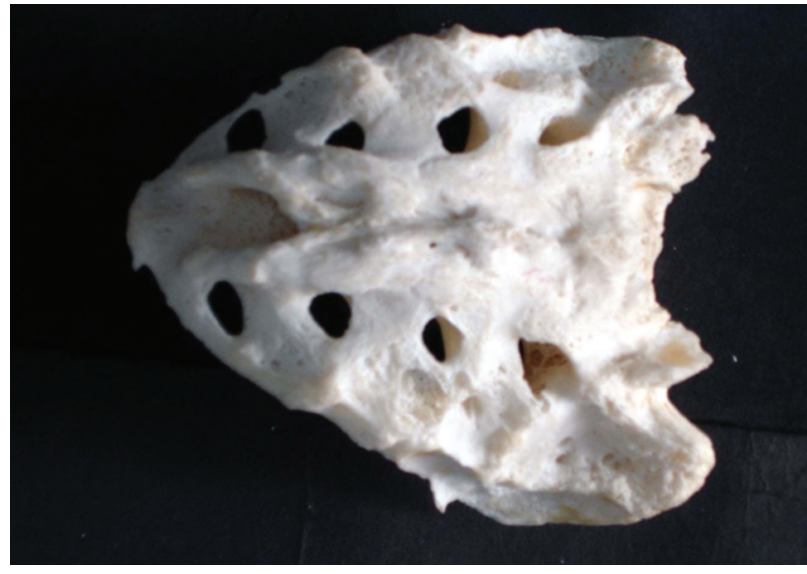

Figure 5. Irregular shaped sacral hiatus.

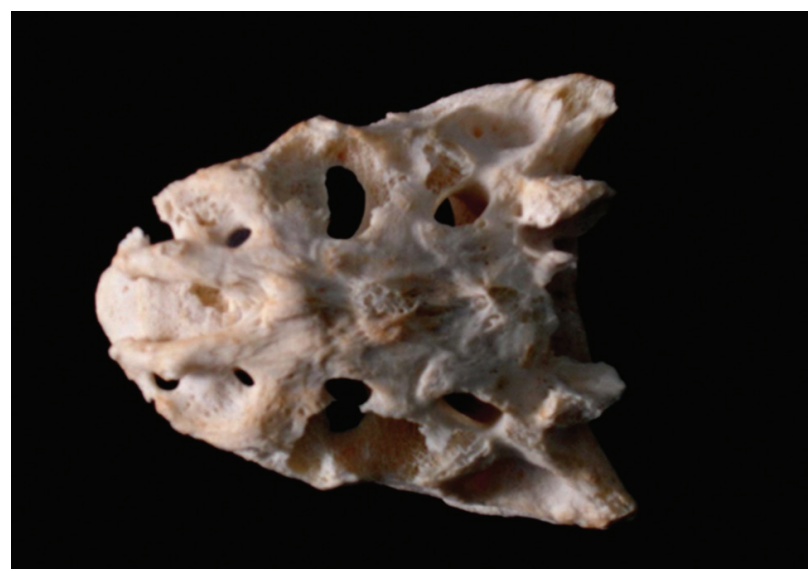

Figure 6. Bifid sacral hiatus.

hiatus, most common being Inverted $\mathrm{V}$ and Inverted $\mathrm{U}$ in $76.23 \%$ sacra and $68.5 \%$, sacra respectively.

7.63\% (KUMAR, PANDEY, BAJPAI et al., 1992) and $13.3 \%$ (NAGAR, 2004) sacra were dumb-bell shaped. In the present study also the shapes of sacral hiatus were variable. Most common was inverted $\mathrm{U}(56 \%)$ and inverted V (14\%). In $10 \%$, the sacral hiatus was dumb-bell, while in $16 \%$ it had irregular outline. Bifid hiatus was seen in $2 \%$ which was reported earlier only by Nagar (2004) having 1.5\% bifid sacra. In addition to this $2 \%$ sacra had elongated hiatus which has not been reported in earlier studies.

In the present study the apex of sacral hiatus was most commonly $(62 \%)$ seen at the level of $3^{\text {rd }}$ sacral vertebrae. Williams (2000) states that the apex of sacral hiatus is present at the level of $4^{\text {th }}$ sacral vertebrae. Various studies reported the apex to be at $4^{\text {th }}$ sacral segment namely Nagar (2004) in $55.9 \%$, Kumar, Pandey, Bajpai et al. (1992) in $76.23 \%$ and Sekiguchi, Yabuki, Saton et al. (2004) in 64\% cases. In other studies Trotter et al. (1944, 1947) and Lanier, McKnight and Trotter (1944) have reported in their series the mean level to be at the lower $3^{\text {rd }}$ of $4^{\text {th }}$ sacral vertebrae. Thus all studies including the present noted that location of apex can vary from upper end of S3 to lower part of S4. The higher level in the present study can be due to racial differences between the subjects.

The base of sacral hiatus was seen at level of S5 vertebrae in $62 \%$ sacra while Nagar (2004) reported $72.6 \%$ at $\$ 5$ and
Kumar, Pandey, Bajpai et al. (1992) reported it to be $83.17 \%$ at S5 vertebrae. In $24 \%$ cases the base was at $4^{\text {th }}$ sacral segment, while for Nagar (2004) it was $11.1 \%$ at S4 level. It extended to coccyx in $14 \%$ cases while for Nagar (2004) it was $16.3 \%$. These sacra had coccygeal ankylosis.

The length of sacral hiatus varied from $5 \mathrm{~mm}$ to $50 \mathrm{~mm}$, it was between $11-30 \mathrm{~mm}$ in about $2 / 3$ sacra i.e $57 \%$, Nagar (2004) observed about $65.8 \%$ sacra between $11-30 \mathrm{~mm}$. The mean length in the present study is $25.2 \mathrm{~mm}$, while Kumar, Pandey, Bajpai et al. (1992) observed mean length of hiatus as $20 \mathrm{~mm}$ in males and $18.9 \mathrm{~mm}$ in females. Trotter and Lanier (1945) have reported length as $24.8 \mathrm{~mm}$ in American males and $19.8 \mathrm{~mm}$ in females. Similar results were noted earlier by Lanier, McKnight and Trotter (1944) as $25.3 \pm 9 \mathrm{~mm}$ as the mean length of hiatus.

The anteroposterior diameter of sacral canal at apex of sacral hiatus is important as it should be sufficiently large to admit a needle. Various diameters lead subcutaneous deposition of anesthetic drug. In the present study the diameter ranged from $2-12 \mathrm{~mm}$ with a mean of $5.53 \mathrm{~mm}$. Mean diameter as observed by various workers are - Nagar (2004) $-4.8 \mathrm{~mm}$ (range from 2-14mm), Trotter et al. (1944) -5.3mm (range from 0-11mm), Lanier, McKnight and Trotter (1944) $-6.1 \mathrm{~mm} \pm 0.2 \mathrm{~mm}$, Kumar, Pandey, Bajpai et al. (1992) -4.8 $\mathrm{mm}$ and Sekiguchi, Yabuki, Saton et al. (2004) $-6.0 \pm 1.9 \mathrm{~mm}$. In the present series sacra had anteroposterior diameter of sacral canal at apex of less than $3 \mathrm{~mm}(5 \%)$ which is equal to Trotter (1947) who reported 5\% cases with $0-2 \mathrm{~mm}$ diameter and Lanier, McKnight and Trotter (1944) noted no case with diameter of less than $3 \mathrm{~mm}$, while it is less than that of Nagar (2004) who reported about $15.6 \%$ cases with diameter less than $3 \mathrm{~mm}$.

The width at base of sacral hiatus varied from $3-25 \mathrm{~mm}$, in more than half $(52 \%)$ cases it was more than $16 \mathrm{~mm}$ and in $46 \%$ cases varied between $6-15 \mathrm{~mm}$ with mean of $19.5 \mathrm{~mm}$. This was almost similar to studies of Trotter and Letterman (1944) who noted the width at base to vary from 7-26mm with mean of $17 \mathrm{~mm}$. Lanier, McKnight and Trotter (1944) reported mean width at base to be $19.3 \pm 0.3 \mathrm{~mm}$ and Kumar, Pandey, Bajpai et al. (1992) who reported 5-20 mm in males and $8-18 \mathrm{~mm}$ in females. Sekiguchi, Yabuki, Saton et al. (2004) have reported a lower figure of $10.2 \pm 0.35 \mathrm{~mm}$. Nagar (2004) reported $0.3-19 \mathrm{~mm}$ variation with $10-15 \mathrm{~mm}$ in $54 \%$ cases and $6-15 \mathrm{~mm}$ in $84 \%$ cases.

Below is the Table 7 for Comparing the Features and Dimensions of the sacral hiatus in different Studies:

\section{Conclusion}

Thus, there is variability in the anatomical structure of sacrum, especially the sacral hiatus. The surgical treatment requiring caudal epidural anesthesia can be much helped by knowing their variations which could improve the success rate of this procedure. In the present study the level of apex of sacral hiatus was found at the level of Sacral $3^{\text {rd }}$ vertebrae in significant percentage, which was in contrast to other studies. This might be due to racial differences between the subjects as this study used sacra from Caucasian race procured from Germany, while other studies were done on other races like Dravidians in India, Mongols in Japan etc. Also the length of sacral hiatus was longer in large percentage of specimens, which should be kept in mind while giving caudal epidural 
anesthesia in this race. However, with advances in surgical methods and instrumentation in the field of Spinal surgery, there is continued need to better understand the anatomy of this region, as caudal epidural anesthesia is widely used for diagnosis and treatment of lumbar spinal disorders in Orthopedics. Further clinical trials are required to compare the existing techniques and our anatomical description to provide more accurate data to support the results of this study.

\section{References}

CHEN, PC., TANG, SFT., HSU, TC., TSAI, WC., LIU, HP., CHEN, MJ., DATE, E. and LEW, HL. Ultrasound guidance in Caudal epidural needle placement. Anesthesiology, 2004, vol. 101, p. 1814. PMid:15220789. http://dx.doi.org/10.1097/00000542200407000-00028

EDWARDS, WB. and HINGSON, RA. Continuous caudal anesthesia in Obstetrics. American Journal of Surgery, 1942, vol. 57, p. 459-464. http://dx.doi.org/10.1016/S0002-9610(42)90599-3

KUMAR, V., PANDEY, SN., BAJPAI, RN., JAIN, PN. and LONGIA, GS. Morphometric study of sacral hiatus. Journal of Anatomical Society of India, 1992, vol. 41, n. 1, p. 7-13.

LANIER, Vs., McKNIGHT, HE. and TROTTER, M. Caudal analgesia: An experimental and anatomical study. American Journal of Obstetrics and Gynecology, 1944, vol. 47, n. 5, p. 633-641.

LETTERMAN, GS. and TROTTER, M. Variations of the male sacrum; Their significance in caudal analgesia. Surgery Gynecology \& Obstetrics, 1944, vol. 78, n. 5, p. 551-555.

NAGAR, SK. A Study of Sacral Hiatus in Dry Human Sacra. Journal of the Anatomical Society of India, 2004, vol. 53, n. 2, p. 7-12.
SEKIGUCHI, M.,YABUKI, S., SATON, K. and KIKUCHI, S. An anatomical study of the sacral hiatus: A basis for successful Caudal Epidural block. Clinical Journal of Pain, 2004, vol. 20, n. 1, p. 5154. PMid:14668657. http://dx.doi.org/10.1097/00002508200401000-00010

SENOGLU, N., SENOGLU, M., OKSUZ, H., GUMUSALAN, Y., YUKSEL, KZ., ZENCIRCI, B., EZBERCI, M. and KIZILKANAT, E. Landmarks of the sacral hiatus for caudal epidural block: An anatomical study. British Journal of Anaesthesiology, 2005, vol. 95, n. 5, p. 692-695. PMid:16155035. http://dx.doi.org/10.1093/ bja/aei236

TROTTER, M. and LANIER, PF. Hiatus canalis sacralis in American Whites and Negros. Human Biology, 1945, vol. 17, p. 368-381. PMid:21015697.

TROTTER, M. and LETTERMAN, GS. Variations of the female sacrum; Their significance in continuous caudal analgesia. Surgery Gynecology \& Obstetrics, 1944, vol. 78, n. 4, p. 419-424.

TROTTER, M. Variations of the sacral canal; Their significance in the administration of caudal analgesia. Anesthesia and Analgesia, 1947, vol. 26, n. 5, p. 192-202. PMid:20262465.

WHITE, AH., DERBY, R. and WYNNE, G. Epidural injections for the treatment of low back pain. Spine, 1980, vol. 5, p. 7886. PMid:6444766. http://dx.doi.org/10.1097/00007632198001000-00014

WILliamS, PL. Gray's Anatomy. 38th ed. Churchill Livingstone, 2000. vol. 530-531, p. 673-674.

Received May 21, 2013

Accepted March 27, 2014 